\title{
Stendhal's Syndrome
}

Before the 19th century, there were travellers. There were even rich Englishmen doing the Grand Tour. But then, somewhere around the time of the French Revolution (or perhaps a little before it) feelings were let loose on the world. Back in 1761, readers had swooned when they encountered the 'true voice of feeling' in Jean-Jacques Rousseau's novel La Nouvelle Héloïse; by the end of the decade, all of Europe was being sentimental in the manner made fashionable a few years later by Laurence Sterne in his A Sentimental Journey. Then there was Goethe's novella, The Sorrows of Young Werther (1774), which made its author a celebrity and a visit to Weimar where Goethe eventually ended up working as a civil servant (and bitterly regretted his youthful work) - a must for anybody with cultural pretensions. Everybody came to visit, including Napoleon, who reputedly carried a copy of the novel with him on his military campaign.

And it was in Napoleon's entourage that a young man from Grenoble, Marie-Henri Beyle, known through his writing as Stendhal, earned his spurs. He made his first acquaintance with Italy in 1800 , when he crossed as a dragoon with the army of liberation over the Grand Saint-Bernard pass to fight the Austrians, and it was to remain his country of predilection. And he 'fell', as he put it, with Napoleon in 1814. After the Treaty of Fontainebleau, he settled for a while in Milan, and later in life was to be French consul at Trieste (then run by Austria) and Civitavecchia. Many of his greatest books are set in Italy, including his autobiography The Life of Henry Brulard (Brulard was one of his many aliases), which opens with the writer looking out from the Janiculum Hill with 'the whole of Rome ... from the ancient Appian Way with the ruins of its tombs and aqueducts to the magnificent garden of the Pincio, built by the French, spread out before [him].' $\mathrm{He}$ travelled widely, briefly visited Spain, spent 2 years as a quartermaster in northern Germany (whence his pen-name) and of course was in Russia with the Grande Armée, on a journey to Moscow and back that turned into a horrendous saga of frostbite and starvation. He visited London three times, and even contributed articles to English-language journals on the cultural life of Paris. Stendhal liked to pepper his French with anglicisms, and was one of the first writers to popularise the use of the word 'tourist' in French.

It was on one of his visits to Italy in 1817 that Stendhal described an experience that brought the literary swoon into tourism. Visiting the Basilica of Santa Croce, he found a monk to let him into the chapel where he could sit on a genuflecting stool, tilt his head back and take in the prospect of Volterrano's fresco of the Sibyls without interruption. The pleasure was keen. 'I was already in a kind of ecstasy,' he writes, 'by the idea of being in Florence, and the proximity of the great men whose tombs I had just seen. Absorbed in contemplating sublime beauty, I saw it close-up - I touched it, so to speak. I had reached that point of emotion where the heavenly sensations of the fine arts meet passionate feeling. As I emerged from Santa Croce, I had palpitations (what they call an attack of the nerves in Berlin); the life went out of me, and I walked in fear of falling.' It was something he had observed about himself: 'when a thought takes too strong a hold of me,' he writes in his autobiography, 'I fall down."

There were to be many cases resembling Stendhal's experience in the 19th-century the hypersensitive Marcel Proust had constant attacks of the vapours (and asthma) writing his novel In Search of Lost Time, and Dostoevsky is known to have become terribly agitated when he saw the famous painting of the dead Christ by
Hans Holbein in Basle (and made his pregnant wife fear he was going to have one of his epileptic fits). ${ }^{1}$ The German poet Rainer Maria Rilke wrote in his first Duino Elegy: 'beauty is nothing but the beginning of terror, which we are still just able to endure, and we are so awed because it serenely disdains to annihilate us.' Philosophers were getting in on the act too. Immanuel Kant, in his Critique of Judgement, hypothesised that the contemplation of aesthetically stimulating objects induces 'a rapidly alternating repulsion and attraction produced by one and the same object. The point of excess for the imagination ... is like an abyss in which it fears to lose itself.' Kant's ideas were further developed in the 19th-century, when aesthetics abandoned the classical idea of imitation and took on the idea that contemplating an object might be a selfactivity experienced as an attribute of the object. This kind of involuntary emotional projection was called Einfühlung: it is the German word that was brought into English as 'empathy'.

Stendhal's syndrome isn't one of the disorders in the latest version of the Diagnostic and Statistical Manual of Mental Disorders, but with the nosological inventiveness that the manual has shown in recent years, it is probably just a matter of time. In 1989, an Italian psychiatrist at the Santa Maria Nuova hospital in Florence
The Basilica di Santa Croce, Florence, Italy.

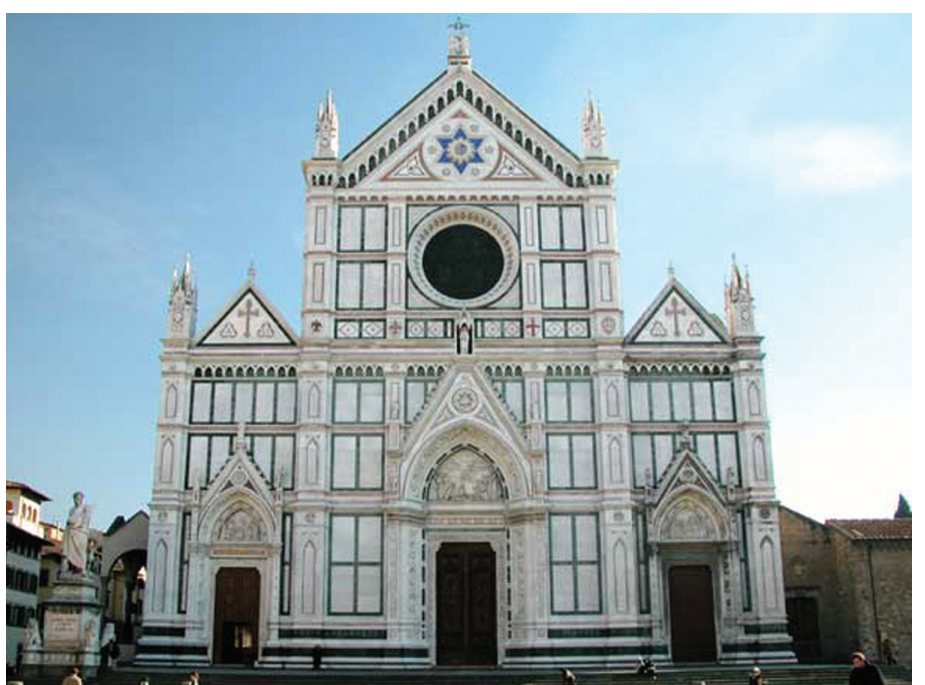


wrote up her observations on the 106 visitors who had been treated as emergencies and even hospitalised in her department in the previous decade. Most of them had been stretchered straight to the hospital from the city's art galleries and museums. Their symptoms included dizzy spells, palpitations, hallucinations, disorientation, loss of identity, and physical exhaustion. Precipitating factors were 'an impressionable personality, the stress of travel and the encounter with a city like Florence haunted by ghosts of the great, death and the perspective of history.' Treatment? Getting out of Italy as soon as possible and back to mundane reality. In honour of Stendhal's visit to the city she dubbed this phenomenon 'Stendhal's syndrome'. ${ }^{2,3}$

But is Stendhal's syndrome anything new? In religious times, pilgrims had felt a sense of exaltation on arriving in Rome, the caput mundi: the experience of feeling a little bit lighter (in all senses) once they get to their destination is an experience common to pilgrims across the world, from Mecca to Santiago de Compostela. A prolonged journey is an archetypal experience: we enjoy reading travel literature because it allows us to share vicariously the author's conviction of being on a quest. Goethe's famous Italian journey of 1786 was one such, and he thought he would have been 'a lost man' if he hadn't been able to see Italy when he did. And there is nothing new about the urge to sightsee: the Greeks were doing it in antiquity, and Herodotus and Callimachus had already tried to meet the demand for tourist attractions ('mirabilia') by listing the Seven Wonders around the shores of the Mediterranean. Even in those days travellers came back with useless souvenirs.

It is among religious travellers that Stendhal's syndrome seems to have found its most florid expression. Ten years ago a team of psychiatrists at the Kfer Shaul Mental Health Centre in Jerusalem reported an acute psychotic state they called the 'Jerusalem syndrome'. ${ }^{4}$ Jerusalem, as they write, is a city regarded in terms of 'the holy, the historical, and the heavenly' by adherents of three of the world's religions, who often overlook the politically divided, noisy, and bustling modern city. Tourists suffering from psychotic decompensation in Jerusalem are all referred to their facility: on average, about 100 patients a year, 40 of whom require admission. They identified three types of patients: those with preexisting problems, usually pathological identification with a character or idea, those with borderline personality disorders, and previously normal persons experiencing a short-lived acute psychotic episode, similar in many ways to Stendhal's syndrome but manifested by a desire to sing psalms out loud, wrap themselves in hotel bed-linen, or deliver sermons in one of the city's holy places. These otherwise normal patients, they found, tended to have 'an idealistic subconscious image of Jerusalem'. Recovery was invariably spontaneous on leaving Jerusalem.

In his autobiography Memories, Dreams, Reflections Carl Gustav Jung describes how in 1949, by then an old man, he decided to go to Rome, something he had wished to do all his life but had put off, fearing the emotional impact of encountering the heart of Europe's ancient imperial structure. Pompeii, which he had visited earlier in his life, had exerted an effect which 'had very nearly exceeded [his] powers of receptivity'. But on entering a travel agent in Zurich to buy his ticket, he fainted. 'After that, the plans for a trip to Rome were once and for all laid aside'. Jung was never to see the Eternal City because of his idealistic subconscious image. Even Freud, who always seemed to me to be quite level-headed (compared to Jung), had a similar thing about Athens. Of course one way to avoid an experience is not to have it at all.

It's perplexing when so many people you take to be sensible turn out to be histrionic at heart. The journalist Louis Inturissi, in a hilarious piece for the New York Times, suggested that part of the problem with Americans who come down with Stendhal's Syndrome is that they overdose on art. ${ }^{5}$ They have to 'do' Florence, Rome, and Naples in 2 days, and it almost kills them. And many of them really just want to be back home with the telly on. At the other end of the spectrum from the art attack described by Stendhal is another kind of syndrome. Inturissi calls it the Mark Twain Malaise, a cynical mood which overcomes travellers and leaves them totally unimpressed with anything UNESCO has on its universal heritage list. In his The Innocents Abroad, one of the best-selling travel books ever, Twain, who takes some delight in lampooning the grandiose travel accounts of his contemporaries, also suggests that when he saw Leonardo's Last Supper in the dilapidated monastery of Santa Maria delle Grazie in Milan, his first thought was that the copies he had seen back home were so much better than the original. (He was right of course; the painting was in a terrible state until very recently.)

But Mark Twain doesn't have to be pressed into service as our fall-guy. In Nothing to be Frightened Of, his book of musings on his mortal coil, Julian Barnes mentions Stendhal's experience in Florence. Intrigued, he did some research on the original diary entries on the trip to Italy which made Stendhal the 'modern art-lover's progenitor and justification', and found no mention of the arty faint. There was little mention of superlative artworks either. Stendhal's feet were swollen and pinched from his new boots and he wanted to get on the coach to Rome as soon as he could. So there we have it: Stendhal never appears to have had the experience he wrote up in his travelogue. Or at least he had it as Beyle, and wrote it up as Stendhal.

It hasn't stopped hundreds of people reacting to great art in the hope that subject and object will merge in a true fellowship of feeling. That idea is as old as Plato, who still had some qualms about the ritualistic nature of aesthetic objects and the violence of inspiration (as when we talk about being 'struck' by a work of art). Art can be so powerful that we forget its unpredictability, and faint like Mary at the cross. All those scenes were familiar too to Stendhal, who made a cult of spontaneity but whose novels know that in the world of desire a little water is always enough to prime a pump.

\section{lain Bamforth}

\section{REFERENCES}

1. Amâncio EJ. Dostoevsky and Stendhal's Syndrome. Arq Neuropsiquiatr 2005; 63(4): 1099-1103.

2. Magherini G. La Sindrome di Stendhal. Firenze, Ponte Alle Grazie, 1989 [in Italian].

3. Barnas M. Confrontations: an interview with Florentine psychiatrist Graziella Magherini. http://www.metropolism.com/magazine/2008no4/confrontaties/english (accessed 12 Nov 2010).

4. Bar-el Y, Durst R, Katz G, et al. Jerusalem syndrome. Br J Psychiatry 2000; 176: 86-90.

5. Inturrisi L. Going to pieces over masterpieces. http://www.nytimes.com/1988/11/06/travel/going-topieces-over-masterpieces.html (accessed 12 Nov 20

DOI: 10.3399/bjgp10X544780 